\title{
Effects of Eco-frendly Hot Oil Treatment on the Wood Properties of Gmelina Aborea and Cocos Nucifera
}

\author{
Shalehudin D. Ma'ruf ${ }^{1}$ Samsul Bakri ${ }^{1}$ Indra Gumay Febryano ${ }^{2}$ Agus Setiawan ${ }^{2}$ \\ Agus Haryanto $^{3}$ Intan Fajar Suri ${ }^{4}$ Nam Hun Kim ${ }^{4}$ Wahyu Hidayat ${ }^{2, *}$ \\ ${ }^{1}$ Graduate School of Environmental Sciences, Universitas Lampung, Bandar Lampung, Indonesia \\ ${ }^{2}$ Department of Forestry, Faculty of Agriculture, Universitas Lampung, Bandar Lampung, Indonesia \\ ${ }^{3}$ Department of Agricultural Engineering, Universitas Lampung, Bandar Lampung, Indonesia \\ ${ }^{4}$ Department of Forest Materials Engineering, College of Forest and Environmental Sciences, Kangwon National \\ University, Republic of Korea \\ *Corresponding author. Email: wahyu.hidayat@fp.unila.ac.id
}

\begin{abstract}
Most of wood in Indonesia is dominated by fast-growing wood such as gmelina (Gmelina arborea) and materials such as coconut (Cocos nucifera). Using fast-growing woood natural forests, increase economic growth, and is more environment friendly. The objective of this study was to improve the wood properties of G. arborea and $C$. nucifera via hot oil treatment. The experiment was conducted in a lab-scale furnace using a commercial grade palm oil at $180^{\circ} \mathrm{C}, 200^{\circ} \mathrm{C}, 220^{\circ} \mathrm{C}$, and $240^{\circ} \mathrm{C}$ for $3 \mathrm{~h}$. The effect of hot oil treatment on color change, physical, and mechanical properties was evaluated. The results showed that increasing treatment temperature increase of the overall color change $\left(\Delta E^{*}\right)$ in both $G$. arborea and $C$. nucifera. The density of $G$. arborea and $C$. nucifera decreased with increased temperature. The results also showed that increase in temperature reduced the moisture content, density and water absorption in both woods. The compressive strength of $G$. arborea and C. nucifera decreased with the increase in treatment temperature.
\end{abstract}

Keywords: color change, hot oil treatment, mechanical properties, physical properties

\section{INTRODUCTION}

Indonesia $\log$ production increased from 33.41 million $\mathrm{m}^{3}$ in 2013 to 48.74 million $\mathrm{m}^{3}$ in 2018 [1]. The logs come from plantation forests $\left(40.14\right.$ million $\left.\mathrm{m}^{3}\right)$ and natural forests $\left(8.60\right.$ million $\left.\mathrm{m}^{3}\right)$, so that plantations forest are the largest source of logs in Indonesia. Based on [2] data plantation forests are dominated by fastgrowing wood which has a shorter harvest time, so that it has a higher amount of production. Utilization of fastgrowing wood from plantation forests can protect natural forests because fast-growing wood can substitute wood from natural forests, can increase economic growth, and is more environment friendly when compared to other materials such as concrete and steel [3].

However, fast-growing wood has a low density, low strength, high longitudinal shrinkage, and high portion of juvenile wood [4,5]. Therefore, an improvement of wood quality is needed, such as through wood modification. Wood modification can be defined as efforts to improve the quality of wood so as to produce higher quality wood [6,7]. Wood modification consists of chemical modification, impregnation, surface modification, and thermal modification or heat treatment. Heat treatment of wood has more advantages compared to other wood modification techniques because it is considered as an environmentally-friendly modification-technology since no toxic chemicals are used in the process $[7,8]$.

Heat treatment of wood is the application of heat to wood at a temperature ranging between $160^{\circ} \mathrm{C}$ and $180^{\circ} \mathrm{C}$ with a relatively short time [6,9]. Heat treatment of wood has several methods, namely Thermo wood, Plato wood, Rectification, Bois Perdure, and hot oil treatment, which are useful for increasing dimensional stability, resistance to decay and the strength of wood [10]. One method of wood modification that has been used is hot oil treatment which is a method of heating wood in an oil medium at a certain time and temperature. 
Research on hot oil treatment has been conducted by [11] which states that the treatment could increase the biological durability of wood against rot fungi on alder(Alnus glutinosa) wood. According to [12], hot oil treatment on Pinus radiata wood can degrade hemicellulose (up to 70\%), less hygroscopic and more dimensionally stable. Fast growing woods such as Gmelina arborea and Cocos nucifera woods have not been much studied in wood modification especially by hot oil treatments other needs to be research on hot oil treatment in both woods.

The objective of this study was to determine the effect of treatment temperature during hot oil treatment on the color change, physical, and mechanical properties of $G$. arborea and $C$. nucifera woods. G. arborea as a fast-growing wood and C.nucifera as an alternative woody material are expected to be able to replace the function of wood because it has the same chemical composition as cellulose, hemicellulose, and lignin [13] so can reduce wood usage

\section{MATERIALS AND METHODS}

\subsection{Materials Preparation}

The main materials of this research were Gmelina arborea and Cocos nucifera woods. Vegetable oil in the form of commercial palm oil was used as a heat transfer media. G. arborea and C. nucifera woods with a certain age were obtained from community forests. The log was then converted to a board measuring $300 \mathrm{~mm}$ (length) $\times$ $90 \mathrm{~mm}$ (width) $\times 20 \mathrm{~mm}$ (thickness) for colour measurement before and after hot oil treatment. For testing physical and mechanical properties boards with size of $40 \mathrm{~mm}$ (length) $\times 20 \mathrm{~mm}$ (width) $\times 20 \mathrm{~mm}$ (thickness) were used. The boards were dried in stages and stored in a conditioning chamber at room temperature $\left(25^{\circ} \mathrm{C}\right)$ and $\pm 80 \%$ relative humidity until the sample moisture content reaches an equilibrium moisture content. The boards were then sorted, and only boards with normal fiber and free from defect were selected as samples.

\subsection{Hot Oil Treatment Process}

Wood samples were prepared using metal stickers and the top pile was retained using a metal holder to prevent the wood from floating during the treatment process (Fig. 1). Vegetable oil was then put into the furnace. Modification of heat was carried out in the following stages: the temperature was raised from the initial temperature of the oil $25-30^{\circ} \mathrm{C}$ to the maximum temperature target with a heating rate of $4{ }^{\circ} \mathrm{C} / \mathrm{min}$. The maximum temperature was maintained for 3 hours. The maximum temperature target was $180^{\circ} \mathrm{C}, 200^{\circ} \mathrm{C}, 220^{\circ} \mathrm{C}$ and $240^{\circ} \mathrm{C}$.

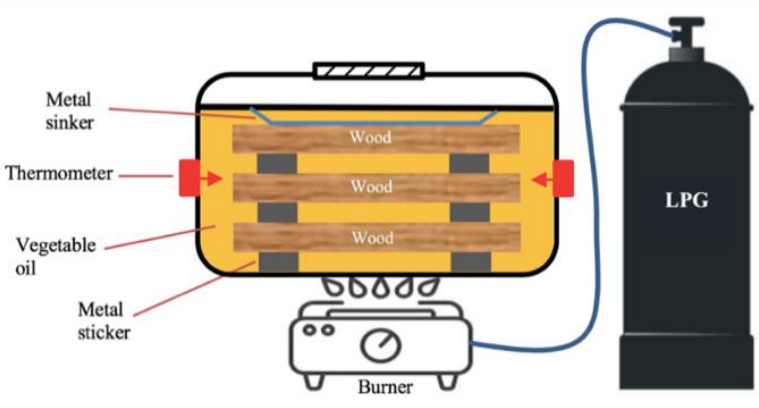

Figure 1 Furnace design for hot oil treatment

\subsection{Board Evaluation}

Color change was measured using a color meter (AMT 507, China) and comparing the colors before and after hot oil treatment to calculate the differences of $\triangle L^{*}$ (light and dark), $\triangle a^{*}$ (red and green), $\triangle b^{*}$ (yellow and blue), and $\triangle E^{*}$ (overall color change).

$$
\begin{aligned}
& \Delta E=\sqrt{\Delta L^{* 2}+\Delta a^{*^{2}}+\Delta b^{* 2}} \\
& \Delta L^{*}=L^{*}{ }_{2}-L^{*} \\
& \Delta a^{*}=a^{*}{ }_{2}-a^{*} \\
& \Delta b^{*}=b^{*}{ }_{2}-b^{*}{ }_{1}
\end{aligned}
$$

where $L^{*}{ }_{1}$ and $L^{*}{ }_{2}$ are the brightness of sample before and after oil heat treatment, $a^{*}{ }_{1}$ and $a^{*}{ }_{2}$ are red and green chromaticity of sample before and after oil heat treatment, $b^{*}$ and $b^{*}{ }_{2}$ are yellow and blue chromaticity of sample before and after hot oil treatment.

Physical properties included moisture content, density, and water absorption both of wood before and after hot oil treatment. Moisture content (MC) and ovendry density $(\rho)$ of sample were calculated using the following equations:

$$
\begin{aligned}
& \operatorname{MC}(\%)=\frac{\mathrm{W}_{\mathrm{AD}}-\mathrm{W}_{\mathrm{OD}}}{\mathrm{W}_{\mathrm{OD}}} \times 100 \% \\
& \rho\left(\mathrm{g} / \mathrm{cm}^{3}\right)=\frac{\mathrm{W}_{\mathrm{OD}}}{\mathrm{V}_{\mathrm{OD}}}
\end{aligned}
$$

where $\mathrm{W}_{\mathrm{AD}}$ is air-dry weight of sample $(\mathrm{g}), \mathrm{W}_{\mathrm{OD}}$ is ovendry weight of sample $(\mathrm{g})$, and $\mathrm{V}_{\mathrm{OD}}$ is oven-dry volume of sample $\left(\mathrm{cm}^{3}\right)$.

Water absorption (WA) of sample were calculated using the following equation:

$$
\mathrm{WA}(\%)=\frac{\mathrm{W}_{\mathrm{AS}}-\mathrm{W}_{\mathrm{OD}}}{\mathrm{W}_{\mathrm{OD}}} \times 100 \%
$$

where $\mathrm{W}_{\mathrm{AS}}$ is weight after soaking $(\mathrm{g})$.

Mechanical properties testing was used to measure wood strength. This test used the measurement of the compressive strength (CS) of wood before and after hot oil treatment.

$$
\operatorname{CS}\left(\mathrm{N} / \mathrm{mm}^{2}\right)=\frac{\mathrm{F}}{\mathrm{A}}
$$


where $\mathrm{F}$ is maximum load $(\mathrm{N})$ and $\mathrm{A}$ is surface area of the compressed plane $\left(\mathrm{mm}^{2}\right)$.

\section{RESULTS AND DISCUSSION}

\subsection{Color Change}

$G$. arborea and $C$. nucifera woods show change in color after hot oil treatment. The decrease in the value of $\Delta L^{*}$ indicates that the color of the wood is darker so that it will be preferred by consumers. According to [14] the results of consumer preferences test revealed that consumers prefer the darker color of heat-modified wood at $200{ }^{\circ} \mathrm{C}$. Data in Table 1 show that the higher the treatment temperature the higher the value of $\triangle E^{*}$. This shows that the higher the temperature, the higher the wood color change. According to[15; 16; 17] if there is a change in the total color value $(\triangle E)$ exceeding 12.0, it can be stated that the wood color change has been totally changed. This means that in our experiment both wood color has been totally changed after hot oil treatment.

\subsection{Physical Properties}

Both of wood density (Figure 2) decreases when the hot oil treatment temperature gets higher. G. arborea showed less density reduction than $C$. nucifera. Samples of $C$. nucifera exhibits a higher density reduction of $G$. arborea up to $200^{\circ} \mathrm{C}$.

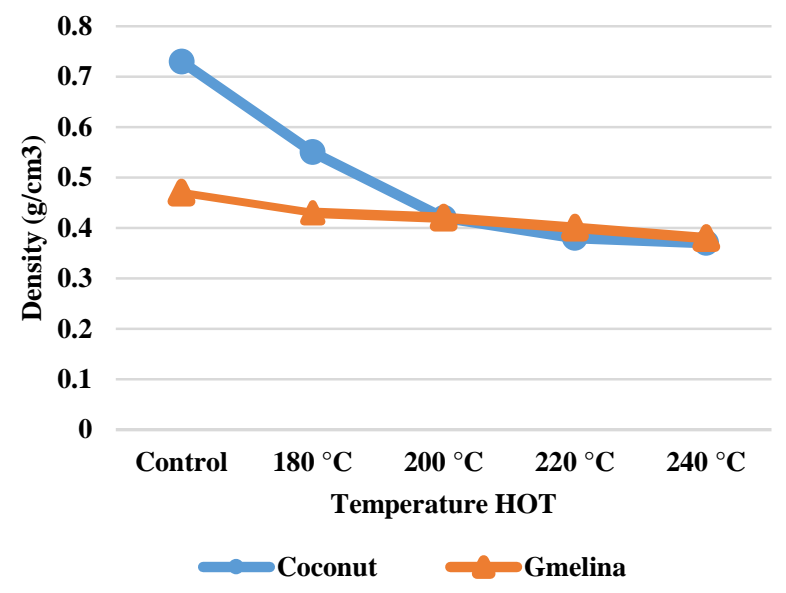

Figure 2 Density of wood after hot oil treatment

The moisture content of woods before hot oil treatment were higher than after treatment and shows a tendency to decrease in moisture content when the treatment temperature gets higher. Heat modification clamping method of the wood can reduce the equilibrium moisture content and density [17, 18,19]. The reduced moisture content of the wood will increase the wood resistance against destructive organisms [8].

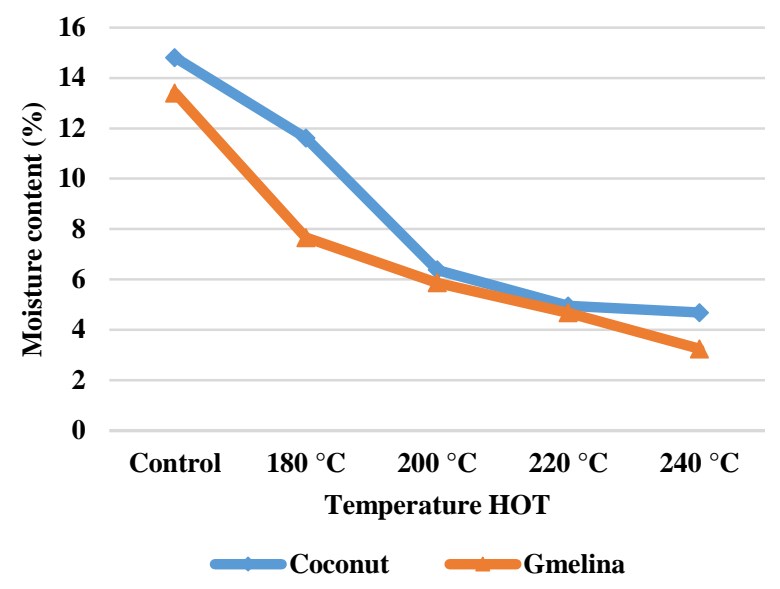

Figure 3 Moisture content of wood after hot oil treatment

Water absorption test shows a decrease in the water absorption of all wood with increasing temperature of treatment (Figure 4). This occurs in accordance with the statement of $[18 ; 20]$ the decrease water absorption of wood with increasing temperature of treatment due to increase in hydrophobicity of cell walls due to the reduced number of hydroxyl groups because chemical reactions during heat treatment. The reduced ability of wood to absorb water will increase the dimensional stability of the wood.

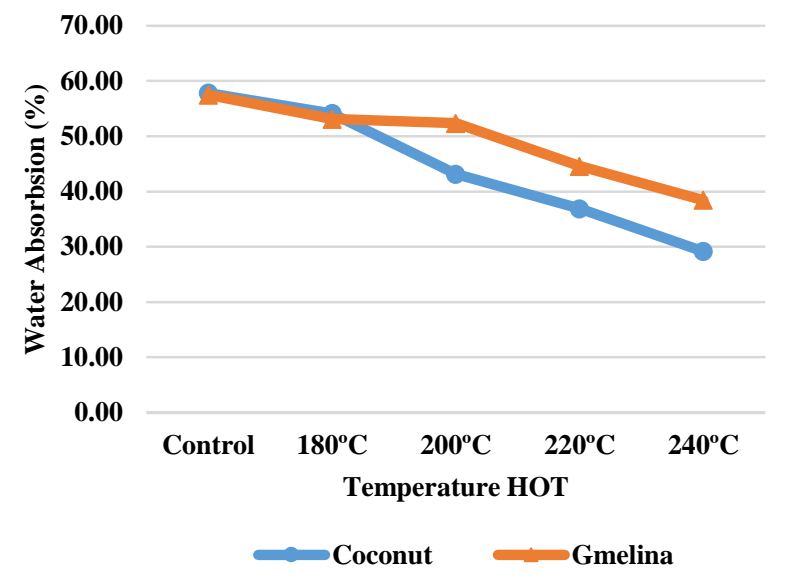

Figure 4 Water absorption of wood after hot oil treatment

\subsection{Mechanical Properties}

The compressive strength of $C$. nucifera is greater than $G$. arborea at all treatment temperatures. Compressive strength in both woods decreased when the treatment temperature gets higher. The results are similar with the previous study [8,21], showing a reduction in mechanical strength with the increase of temperature. 
Table 1. Color change of wood after hot oil treatment

\begin{tabular}{|c|c|c|c|c|c|}
\hline Wood & Treatment & $\Delta \mathrm{L}^{*}$ & $\triangle \mathrm{a}^{*}$ & $\Delta \mathrm{b}^{*}$ & $\Delta \mathrm{E}^{*}$ \\
\hline \multirow{5}{*}{ G. arborea } & Control & $81.52(2.27)$ & $11.93(0.63)$ & $24.02(2.80)$ & \\
\hline & $180^{\circ} \mathrm{C}$ & $54.50(0.59)$ & $11.07(0.66)$ & $20.43(1.81)$ & $28.67(1.04)$ \\
\hline & $200^{\circ} \mathrm{C}$ & $46.49(3.11)$ & $9.75(0.45)$ & $18.33(1.34)$ & $35.85(3.03)$ \\
\hline & $220^{\circ} \mathrm{C}$ & $43.84(2.38)$ & $4.73(1.48)$ & $10.36(2.09)$ & $39.25(2.30)$ \\
\hline & $240^{\circ} \mathrm{C}$ & $38.77(0.64)$ & $3.43(1.60)$ & $5.07(4.08)$ & $46.82(2.27)$ \\
\hline \multirow{5}{*}{ C. nucifera } & Control & $63.01(4.40)$ & $9.65(1.39)$ & $18.73(2.24)$ & \\
\hline & $180^{\circ} \mathrm{C}$ & $46.28(2.78)$ & $10.29(0.38)$ & $15.17(0.99)$ & $15.79(2.91)$ \\
\hline & $200^{\circ} \mathrm{C}$ & $43.00(1.18)$ & 7.59 (1.89) & $13.27(2.71)$ & $23.92(2.28)$ \\
\hline & $220^{\circ} \mathrm{C}$ & $35.53(3.46)$ & $4.90(0.91)$ & $5.92(2.27)$ & $34.48(4.15)$ \\
\hline & $240^{\circ} \mathrm{C}$ & $31.11(0.47)$ & $3.35(0.24)$ & 4.72. (0.57) & $36.73(0.68)$ \\
\hline
\end{tabular}

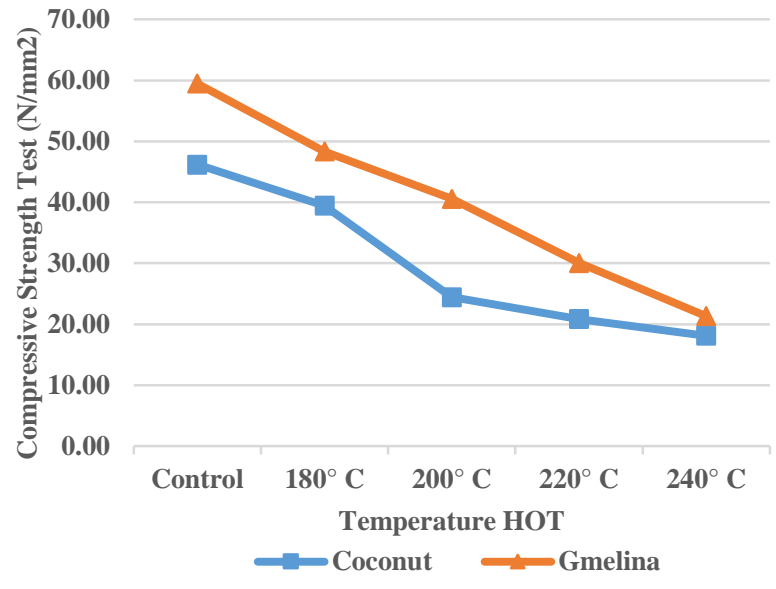

Figure 5 Compressive strength test wood after hot oil treatment

\section{CONCLUSIONS}

The color of $G$. arborea and $C$. nucifera woods totally changed after heat treatment at $180^{\circ} \mathrm{C}$. Hot oil treatment improved the dimensional stability of both woods as shown by lower moisture content and water absorption compared to untreated samples. However, hot oil treatment decreased the compressive strength of $G$. arborea and $C$. nucifera woods, showing an acceptable decrease at treatment temperature of $180^{\circ} \mathrm{C}$.

\section{AUTHORS' CONTRIBUTIONS}

SDM: Conception and experiment design, data collection, analysis and interpretation, writing the article draft.

IFS: Data collection, writing the article draft.

SB, IGF, AS, AH, NHK: Conception and experiment design, critical review and revision the draft.

WH: Obtaining funding, conception and experiment design, critical review and revision the draft, final approval of the article.

\section{ACKNOWLEDGMENTS}

Authors acknowledge the Ministry of Education and Culture of Indonesia for financial support through Thesis Magister Research Grant No. 3869/UN26.21/PN/2020 and 044/SP2H/ LT/DRPM/2020.

\section{REFERENCES}

[1] [KLHK] Kementerian Lingkungan Hidup dan Kehutanan, Statistik Lingkungan Hidup dan Kehutanan, Pusat Data dan Informasi KLHK, Jakarta, 2018.

[2] [BPS] Badan Pusat Statistik, Statistik Produksi Kehutanan, Badan Pusat Statistik (Statistic Indonesia), Jakarta, 2018.

[3] C. Cossalter, C. Pye-Smith, Forest Perspectives: Fast-Wood Forestry Myths and Realities. Jakarta. Center for International Forestry Research, 2003.

[4] R. Shmulsky, P.D. Jones, Forest Products and Wood Science: An Introduction, Sixth Edition, Wiley-Blackwell, 111 River Street, Hoboken, NJ, USA, 2011. DOI: 10.1002/9780470960035

[5] R. Johnson, K. Jayawickrama, Genetics of Wood Specific Gravity in Coastal Douglas-Fir. in: PNWTIRC/NWTIC Workshop on Genetic Improvement of Wood Quality in Coastal DouglasFir and Western Hemlock Department of Forest Science, Oregon State University, 2002.

[6] C.A.S. Hill, Wood Modification: Chemical, Thermal and Other Processes, John Wiley \& Sons, The Atrium, Southern Gate, Chichester, England, 2006. DOI: $10.1002 / 0470021748$ 
[7] B.M. Esteves, H.M. Pereira, Wood modification by heat treatment: A review. Bio Resources 4(1): 370 404, 2009.

[8] W. Hidayat, F. Febrianto. Teknologi Modifikasi Kayu Ramah Lingkungan: Modifikasi Panas dan Pengaruhnya terhadap Sifat-sifat Kayu, Pusaka Media, Bandar Lampung, 2018.

[9] D. Kocaefe, J.L. Shi, D.Q. Yang, M. Bouazara, Mechanical properties, dimensional stability, and mold resistance of heat-treated jack pine and aspen, Forest Products Journal (4): 7452-7465, 2008.

[10] H.I. Sahin, Heat treatment application methods and effects of heat treatment on some wood properties. in: International Conference on Engineering and Natural Science (ICENS), Budapest, 2017, pp: 540-543.

[11] R. Lacić, M. Hasan, J. Trajković, B. Šefc, B. Šafran, R. Despot, Biological Durability of Oil Heat Treated Alder Wood. Drvna Industrija, 65(2):143-150, 2014. DOI: 10.5552/drind. 2014.1256

[12] M.K. Dubey, S. Pang, J. Walker, Changes in chemistry, color, dimensional stability and fungal resistance of Pinus radiata D. Don wood with oil heat-treatment. Holzforschung, 6(1): 49-57, 2012. DOI: $10.1515 /$ HF.2011.117

[13] D. Indrosaptono, S. Sukawi, M.S. Indraswara, Kayu kelapa (glugu) sebagai alternative bahan konstruksi bangunan. Modul 14(1): 53-58, 2014. DOI: $10.14710 / \mathrm{mdl} .14 .1 .2014 .53-58$

[14] W. Hidayat, Y. Qi, J.Y. Jang, B.H. Park, I.S. Banuwa, F. Febrianto, N.H. Kim, Color change and consumer preferences towards color of heat-treated korean white pine and royal paulownia woods. J. Korean Wood Sci. Technol. 45(2): 213-222, 2017.
[15] W. Cui, D.P. Kamdem, T. Rypstra, Diffuse reflectance infrared fourier transform spectroscopy (DRIFT) and color changes of artificial weathered wood. Wood and Fiber Science 36(3): 291-301, 2004.

[16] W. Hidayat, Y. Qi, J.H. Jang, F. Febrianto, N.H. Kim, Effect of mechanical restraint on drying defects reduction in heat-treated Okan wood. BioResources, 12(4): 7452-7465, 2017. DOI: 10.15376/biores.12.4.7452-7465

[17] W. Hidayat, Y. Qi, J.H. Jang, F. Febrianto, N.H. Kim, Effect of mechanical restraint on the properties of heat-treated Pinus koraiensis and Paulownia tomentosa woods. BioResources, 12(4): 7539-7551, 2017. DOI: 10.15376/biores.12.4.75397551

[18] W. Hidayat, J.H. Jang, S.H. Park, Y. Qi, F. Febrianto, S.H. Lee, N.H. Kim, Effect of Temperature and Clamping during Heat Treatment on Physical and Mechanical Properties of Okan (Cylicodiscusgabunensis [Taub.] Harms) Wood. BioResources 10(4): 6961-6974, 2015. DOI: 10.15376/biores.10.4.6961-6974

[19] W. Hidayat, Y. Qi, J.H. Jang, F. Febrianto, S.H Lee, N.H. Kim, Effect of treatment duration and clamping on the properties of heat-treated okan wood. BioResources 11(4): 10070-10086, 2016. DOI: $10.15376 /$ biores.11.4.10070-10086

[20] S. Jamsa, P. Viitaniemi, Heat treatment of wood: Better durability without chemicals," in: Proceeding of special seminar held in Antibes, France, 2001.

[21] W. Hidayat, F. Febrianto, B.D. Purusatama, N.H. Kim, Effects of Heat Treatment on the Color Change and Dimensional Stability of Gmelina arborea and Melia azedarach Woods, in: E3S Web of Conferences, 2018. DOI: 10.1051/e3sconf/ 20186803010 